\title{
Casas com rampas desenhadas por Vilanova Artigas na década de 1960
}

\section{Leonardo Botene da Silva*, Ana Tagliari (orientadora)}

\section{Resumo}

O objeto desta pesquisa são quatro projetos de residências com rampas construídas na cidade de São Paulo na década de 1960 concebidas pelo arquiteto Vilanova Artigas. O objetivo da pesquisa é analisar os projetos selecionados, relacionando com o sistema de circulação e o partido adotado.

\section{Palavras-chave:}

Vilanova Artigas, circulação em arquiteura, rampas.

\section{Introdução}

João Batista Vilanova Artigas (1915-1985) foi um dos mais importantes e influentes arquitetos brasileiros do século XX.O objeto de investigação desta pesquisa são quatro projetos residenciais unifamiliares com rampas construídos na cidade de São Paulo na década de 1960. As residências Manoel Antônio Mendes André (1966), Gilberto Krutman (1968), Telmo Fernandes de Aragão Porto (1968) e Ariosto Martirani (1968).

Figura 1. Residências selecionadas para o estudo.
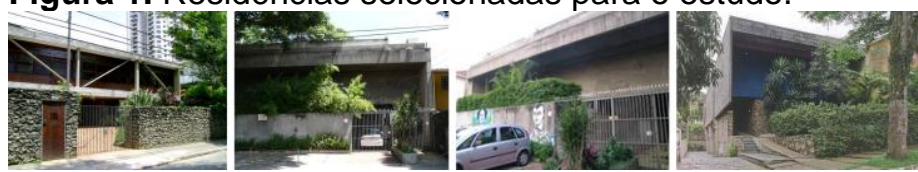

O objetivo desta pesquisa foi estudar os projetos selecionados e investigar como a circulação foi resolvida pelo arquiteto. As rampas são elementos considerados não apenas um elemento de circulação num projeto de Artigas, mas como "mais um ambiente", A circulação é uma necessidade do programa e este elemento cria um ambiente que promove a continuidade visual, espacial e os encontros entre as pessoas.

A investigação destes projetos foi realizada por meio de desenhos, diagramas analíticos e modelos digitais. Os desenhos foram realizados a partir do material disponível na Biblioteca Digital de projetos originais da FAUUSP.

A presente pesquisa se caracteriza como pesquisa científica, cuja contribuição original é investigar estes projetos a partir de um enfoque diferente, inovador e criativo, no objetivo de se entender como o arquiteto definiu na sua prática projetual, a organização dos espaços domésticos e a circulação, além de estabelecer relações com outros projetos do mesmo arquiteto, buscando estratégias e soluções ensaiadas, analogias, semelhanças, diferenças e experiências de projeto.

\section{Resultados e Discussão}

A partir da metade da década de 1940 o projeto residencial de Artigas toma uma nova linguagem, como apontado por importantes autores (Bruand, 2008; Zein, 1984). A adoção de rampas pelo arquiteto não apresenta relação com o debate atual de acessibilidade, mas com a concretização de alguns ideais pretendidos pela Arquitetura Moderna, como a continuidade espacial e visual e importância do percurso para a leitura da arquitetura, como observado por Bruno Zevi (1984) nas sete invariáveis da Arquitetura Moderna e Vincent Scully (2002).

O que observamos nestes projetos, é que a adoção de rampas não está relacionada apenas com o aspecto funcional da circulação, mas fazem parte do programa, estruturam e organizam os ambientes de modo contínuo e fluido, além de atuar como um espaço de convivência e contribuem para isso, em seu percurso e direcionando visuais.

Figura 2. Modelos digitais das casas analisadas.

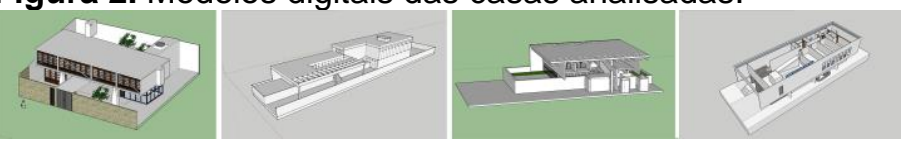

\section{Conclusões}

Esta pesquisa está vinculada ao Grupo de Pesquisa "Arquitetura: Projeto, representação e análise" e à pesquisa com auxílio do CNPq sobre "circulação e percurso em arquitetura".

A ideia de percurso, movimento e circulação como gerador de espaços e formas é algo importante e estruturante no projeto de arquitetura.

Analisar e relacionar os projetos selecionados é uma abordagem criativa e inovadora, que gera conhecimento na área de projeto, teoria e história.

\section{Agradecimentos}

Profa. Dra. Ana Tagliari que desenvolve pesquisas sobre circulação em arquitetura, me acolheu e orientou nesta pesquisa de Iniciação Científica. CNPq e PIBIC Unicamp.

ARTIGAS, Rosa. Vilanova Artigas. São Paulo: Terceiro Nome, 2015. PETROSINO, Maurício Miguel. João Batista Vilanova Artigas - residências unifamiliares: a produção arquitetônica de 1937 a 1981. Dissertação de Mestrado. São Paulo: FAUUSP, 2009.

TAGLIARI, Ana. Modelos conceituais de percurso e circulação no projeto de arquitetura. Revista 5\% Arquitetura + Arte, São Paulo, ano 13, volume 1, número 16, 2018

Tagliari, Ana; PERRONE, Rafael ; Florio, Wilson. As rampas nos projetos residenciais não-construídos de Vilanova Artigas. In: 6º PROJETAR, 2013 Salvador. $6^{\circ}$ PROJETAR - O Projeto como Instrumento para a Materialização da Arquitetura: ensino, pesquisa e prática, 2013.

Tagliari, Ana; PERRONE, Rafael ; Florio, Wilson . Vilanova Artigas. Projetos residenciais não construídos. São Paulo: Annablume Editora, 2017. 